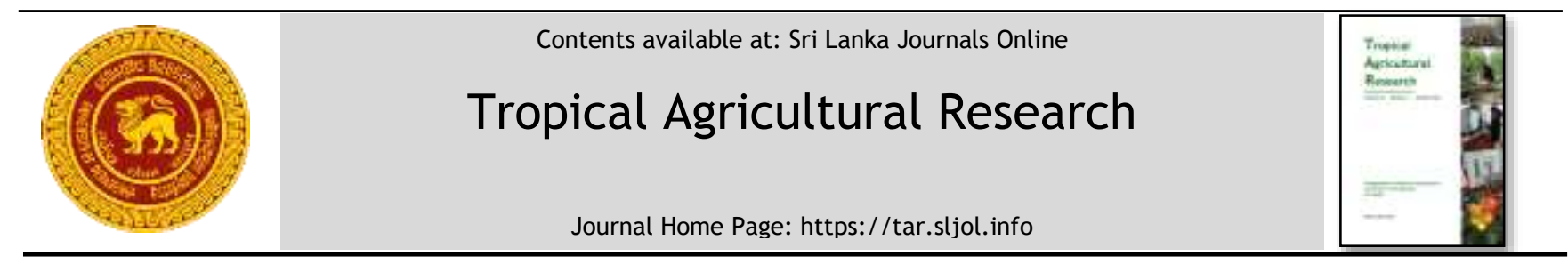

\title{
Potassium Application Rates for Tomato Grown in Soilless Culture under Hot and Humid Greenhouse Conditions
}

\author{
H.R.U.T. Erabadupitiya ${ }^{1 *}$, W.A.P. Weerakkody ${ }^{2}$, K.A. Nandasena ${ }^{3}$ \\ ${ }_{1}^{1}$ Postgraduate Institute of Agriculture, University of Peradeniya, Peradeniya, 20400, Sri Lanka. \\ ${ }^{2}$ Department of Crop Science, Faculty of Agriculture, University of Peradeniya, Peradeniya, 20400, Sri Lanka. \\ ${ }^{3}$ Department of Soil Science, Faculty of Agriculture, University of Peradeniya, Peradeniya, 20400, Sri Lanka
}

\section{ARTICLE INFO}

\section{Article history:}

Received: 13 August 2020

Revised version received: 15 October 2020

Accepted: 02 December 2020

Available online: 01 October 2021

\section{Keywords:}

Coco-peat medium

Critical ranges

Hydroponics

Protected culture

Solanum lycopersicum

\section{Citation:}

Erabadupitiya, H.R.U.T., Weerakkody, W.A.P. and Nandasena, K.A. (2021). Potassium application rates for tomato grown in soilless culture under hot and humid greenhouse conditions. Tropical Agricultural Research, 32(4): 462-470.

DOI: http://doi.org/10.4038/tar.v32i4.8514

Erabadupitiya, H.R.U.T.

https://orcid.org/0000-0002-0199-6706

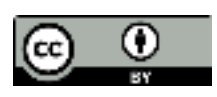

\section{ABSTRACT}

Soilless culture is the most popular cultivation method in greenhouse farming and fertigation in soilless culture determines the qualitative and quantitatively yield of tomato (Solanum lycopersicum L.). The demand for plant nutrients vary with the surrounding environment, growing medium, and plant growth stages of the crops. Most recommended fertilizer dosages for greenhouse crops have been developed to match with the environmental conditions in the temperate region. This study attempted to identify the optimum potassium (K) fertilizer application rates for different growth stages of tomato grown in soilless culture under semi intensive greenhouse environment ( $31 \pm 2{ }^{\circ} \mathrm{C}$ daytime temperature and $75 \%$ relative humidity). Selected dosages of $\mathrm{K}$ for greenhouse tomato ( $\mathrm{K}$ treatments) were compared at advancing growth stages $(0.05-0.4,0.1-0.55$, 0.2-0.6 and 0.25-0.65 g/plant/day) in a replicated trial. At the end of each growth stage, plant growth parameters and leaf tissue nutrients were assessed to compare the $\mathrm{K}$ application rates. Based on growth parameters, marketable yield and plant nutrient contents, the optimum $\mathrm{K}$ fertilizer application rates for vegetative, early reproductive, middle reproductive and late reproductive growth stages of tomato were $0.1,0.2,0.3$ and 0.35 $\mathrm{g} /$ plant/day, respectively. These application rates were able to maintain the plant tissue $\mathrm{K}$ concentrations of 2.5, 2.1, 2.5 and $2.8 \%$ at respective growth stages. Optimum $\mathrm{K}$ application rates identified in this study would be useful for making growth specific fertigation recommendations for greenhouse tomato grown in soilless culture under tropical conditions in order to make protected culture is more cost effective and environmental friendly.

\footnotetext{
*Corresponding author: udani.doa@gmail.com
} 


\section{INTRODUCTION}

Soilless culture is the most popular cultivation method practiced in greenhouse agriculture all over the world. Tomato (Solanum lycopersicom $\mathrm{L}$.) is one of the dominant vegetable crops in greenhouse agriculture. Fertilizer usage is comparatively high in soilless culture since the growing medium needs to be fortified with all the essential nutrients (Sainju et al., 2003). It is a wellknown fact that plant nutrient requirement is dependent on the growth stage of a given crop particularly for macronutrients such as N, P and $\mathrm{K}$ (Bar-Yosef, 1992). The plant nutrient requirement is defined in terms the critical nutrient content in plant tissues. Therefore, plant tissue testing is an important tool for use in achieving a high degree of precision in fertilizer management (Hochmuth et al., 2012). Most recently matured whole leaf is the nutritional status of the plant. In case of tomato, this leaf is usually the fifth or sixth leaf from the apex (Hochmuth, 2001).

Meanwhile the yield and quality of soilless culture tomato depend on the nutrient availability in the growing medium (substrate) (Sainju et al., 2003). A number of internal and external quality parameters of tomato are affected by $\mathrm{K}$ nutrition (Passum et al., 2007; Truffault et al., 2019). Greenhouse growers in Sri Lanka and many other countries apply chemical fertilizers indiscriminately, seeking yield advantages (Erabadupitiya et al., 2019; Ortas, 2013). It has caused to increase the cost of cultivation in soilless culture while polluting soil and water, as $25 \%$ of nutrients and water are drained-out from nonrecirculating soilless culture ("open" type hydroponics) systems (Putra and Yulindo, 2015). Moreover, over dosages of fertilizers affect the harmonious natural nutrient balance in the substrate and thus the availability and uptake of plant nutrients. Increasing $\mathrm{K}$ application does not always improve tomato yield as only $45 \%$ of the $\mathrm{K}$ supplied is absorbed by the greenhouse crops (Voogt and Korsten, 1996) and also it suppresses Ca and Mg uptake (Liu et al., 2011). Therefore, it is needed to provide better guidelines for growers to optimize $\mathrm{N}$ and $\mathrm{K}$ dosages to maintain the expected yield and quality at each growth stage of greenhouse crops. Research done on optimizing $\mathrm{N}$ dosage in soilless culture have been reported earlier for a range of crops and greenhouse environments (Erabadupitiya et al., 2020; Bryson and Barker, 2002; Hochmuth, 2001). Similarly, optimum tissue $\mathrm{K}$ range varies with the crop growth stage (Voogt, 2002), and the growth stage based $\mathrm{K}$ demand have been established for major greenhouse crops (Hochmuth et. al., 2012; Campbell, 2000; Uchida, 2000;). According to the plant nutrient requirements, five main growth stages have been identified for greenhouse tomato crop, namely the nursery stage, vegetative stage, flowering/early reproductive stage, fruiting/middle reproductive stage and heavy fruiting/late reproductive stage in which plant nutrient requirements are variable (Bryson and Barker, 2002; Mayakaduwa et al., 2008; Growing greenhouse vegetables, 2010). Therefore, the recommended $\mathrm{K}$ dosages for maintaining optimum tissue $\mathrm{K}$ levels of a crop grown under temperate conditions and a specific growing medium cannot be directly applied to coco-peat medium grown crops under hot and humid conditions prevail in tropical semi-intensive greenhouses.

Therefore, this study was carried out to determine the plant growth stage specific optimum $\mathrm{K}$ application rates for tomato grown in coco-peat medium based soilless culture under hot and humid greenhouse conditions prevail in the tropics.

\section{METHODOLOGY}

A field study was conducted under greenhouse conditions (having semi-intensive environment controls) in the University Experimental Farm at Meewathura, Peradeniya (agro-ecological zone; WM2) during May-September, 2018. The day and night temperatures of the greenhouse were at 29$33^{\circ} \mathrm{C}$ and $26-28{ }^{\circ} \mathrm{C}$, respectively, while the day time relative humidity was at $75-80 \%$ during the season.

\section{$K$ treatments and soilless culture of tomato}

The seeds of tomato cv. Larisa F1 [Best Seed (Pvt.) Ltd., Colombo, Sri Lanka] were propagated in plastic crated, using properly washed coco-peat (coconut pith with nearly $10 \%$ of coconut fiber) as the growing medium under greenhouse conditions. Since coco-peat does not contain significant plant nutrients since, available salt in coir dust can be easily removed with a heavy irrigation (Cresswell, 1992). The plants in the nursery were supplied with a foliar application of Albert's fertilizer, (CIC (Pvt.) Ltd., Colombo, Sri Lanka), a hydroponics fertilizer twice a week (a routing practice recommended for greenhouse nursery management). At the end of the four weeks nursery period seedlings were transplanted to vertically oriented coco-peat filled $12 \mathrm{~L}$ dual colored polythene grow bags, having drainage holes at the bottom. The coco-peat medium was thoroughly washed and steam sterilized before using as a 
Table 1. Potassium application rates under each $\mathrm{K}$ treatment at different growth stages of tomato

\begin{tabular}{lccccccc}
\hline \multirow{2}{*}{ Growth stage } & \multicolumn{7}{c}{ K application rates in treatments (g/plant/day) } \\
\cline { 2 - 8 } & $\mathrm{T} 1$ & $\mathrm{~T} 2$ & $\mathrm{~T} 3$ & $\mathrm{~T} 4 \mathrm{~b}$ & $\mathrm{~T} 5$ & $\mathrm{~T} 6$ & $\mathrm{~T} 7$ \\
\hline Vegetative stage (1-3 WATa) & 0.05 & 0.10 & 0.20 & 0.25 & 0.3 & 0.35 & 0.4 \\
Early reproductive (4-7 WAT) & 0.10 & 0.20 & 0.30 & 0.35 & 0.4 & 0.5 & 0.55 \\
Middle reproductive (8-11 WAT) & 0.20 & 0.30 & 0.40 & 0.45 & 0.5 & 0.55 & 0.60 \\
Late reproductive (12-15 WAT) & 0.25 & 0.35 & 0.45 & 0.50 & 0.55 & 0.60 & 0.65 \\
\hline
\end{tabular}

a WAT: Weeks after transplanting

${ }^{\mathrm{b}} \mathrm{K}$-rate widely practiced by commercial farmer

growing medium where its chemical properties ( $\mathrm{pH}$ of 6.5 and EC of $0.6 \mathrm{mS} \mathrm{cm}^{-1}$ ) were within the recommended range (Cresswell, 1992). Grow bags were kept at the planting density of 3 plants $/ \mathrm{m}^{2}$ and on plastic trays (in order to collect the leachate and circulate 1-2 times per day). Crop management practices including plant protection were done as described by Weerakkody et al., (2008). As plants grew, all lateral shoots were removed manually and the main stem was trained to a vertical string.

The experiment was laid-out according to a RCBD, having seven potassium $(\mathrm{K})$ dosage treatments (specific for each growth stage) and three replicates. Potassium treatments were decided to maintain a gradual deviation towards higher as well as lower sides from the widely practiced $\mathrm{K}$ dosage by commercial farmers (T4) (Erabadupitiya et al., 2019). Potassium supply in each treatment was maintained by toping up of the $\mathrm{K}$ dosage available in the standard dosage of Alberts fertilizer ( $\mathrm{K}$ ranged 0.3-0.1 g per plant) with commercial grade $\mathrm{KCl}$. Total potassium rate applied in each treatment were ranged within 0.05$0.4,0.1-0.55,0.2-0.6$ and $0.25-0.65 \mathrm{~g} / \mathrm{plant} /$ day in vegetative [1-3 weeks after transplanting (WAT)], early reproductive stage (4-7 WAT), middle reproductive stage (8-11 WAT) and late reproductive stage (12-15 WAT), respectively (Table 1). At the end of the growth stages, total $\mathrm{K}$ contents supplied for treatments K1 through K7 were 16, 26, 36, 42, 47, 54 and $59 \mathrm{~g} / \mathrm{plant}$. The optimum $\mathrm{N}$ application rates developed earlier (Erabadupitiya et al., 2020), were applied to supplement nitrogen at each growth stage $(0.01$, $0.05,0.09$ and $0.14 \mathrm{~g} / \mathrm{plant} /$ day) at the above mentioned four growth stages, respectively and $\mathrm{N}$ rates were adjusted using calcium nitrate. Meanwhile, Phosphorus and other essential plant nutrients were supplied at the standard dosage (Saparamadu et al., 2011) using Albert's fertilizer [CIC (Pvt.) Ltd., Colombo, Sri Lanka], the most popular source of plant nutrients for soilless culture vegetable cultivations in Sri Lanka (Erabadupitiya et al., 2019).
The irrigation volume was increased from 500 $\mathrm{mL} /$ plant/day, to $1200 \mathrm{~mL} /$ plant/day along with the advancing plant growth stages using reported by Mawalagedera et al., (2012) for semi-intensive greenhouse conditions in the tropics, assuring adequate moisture availability (without significant plant nutrients) in the growing medium throughout the day. The drainage collection (10$20 \%$ of the supply volume) were applied back to the growing medium manually (at individual plant basis) within the latter part of the day in order to assure the full availability of the $\mathrm{K}$ dosage. The EC and $\mathrm{pH}$ levels of the supply solution were at the range of $2-3 \mathrm{mS} \mathrm{cm}^{-1}$ and 5.6-6.5, respectively across the K treatments. At the end of each growth stage, growth medium was flushed out with water until the medium was free from accumulated plant nutrients, bringing the $\mathrm{pH}$ and $\mathrm{EC}$ back to the initial level (pH-6.5, EC-0.5-0.6 mScm-1).

\section{Assessment of plant growth and tissue nutrient composition}

Plant growth was analyzed in terms of plant height, stem diameter (at $15 \mathrm{~cm}$ below the growing tip), number of leaves, third leaf length, total leaf area and total shoot dry weight per plants at each growth stage. Measurement of third leaf length was from tip to the end of petiole of the third leaf from the apex. Total leaf area was measured using leaf area meter (AM 350, ADC Bioscientific Ltd.) and the dry weight of the shoot (leaves, stem and flower/fruit clusters) was taken after drying in hot air oven (placed in paper bags) at $70{ }^{\circ} \mathrm{C}$ for $36-48$ hours until constant weight was obtained. It was followed by assessment of number of flower clusters at the early reproductive stage and weekly sampling of mature ripened fruits at the middle and late reproductive stages for determining the marketable yield and yield parameters.

The tissue nutrient contents (N, P, K, Ca and Mg) of the fifth leaf of tomato plants were analysed at the end of each growth stage. The fifth leaf (with petiole) from the apex of tomato plant in each treatment were sampled, covered with tissues and taken for laboratory analysis. The samples were 
oven dried and ground to prepare tissue samples for plant nutrient analysis for total N, P, K, Ca and $\mathrm{Mg}$. Total nitrogen content was determined using the Kjeldahl procedure. The analysis of $\mathrm{P}$ and $\mathrm{K}$ was carried out after dry ashing of $1 \mathrm{~g}$ of prepared tissue samples in a muffele furnace $\left(450{ }^{\circ} \mathrm{C}\right)$ and dissolve in nitric acid to obtain a plant extract. Phosphorus in plant tissue was determined through Olsen method using a visible light spectrophotometer at $880 \mathrm{~nm}$ while $\mathrm{K}$ and Ca were determined using a flame photometer method. An atomic absorption spectrophotometer was used to determine leaf tissue Mg content. In addition to that, temperature and day and night relative humidity within and outside the greenhouse were also recorded.

\section{Statistical analysis}

Biofilm-forming ability was compared by analysing the differences in the degree of biofilm formation using one-way ANOVA and Duncan's multiple range test in SPSS (IBM) software (Version 15, IBM). The parametric data were analyzed at each growth stages separately. For vegetative growth stage data were analyzed through the PROC ANOVA procedure while other stages; early reproductive, middle reproductive and late reproductive stages, data were analyzed using analysis of covariance (ANCOVA). Leaf areas (LA) and shoot dry weights (SDW) of vegetative stage were used as covariates for LA and SDW analysis in early reproductive stages and the SDW of vegetative stage was used as the covariate for number of flower cluster in early reproductive stage. Similarly, LA and SDW of previous growth stages were used as covariates of LA and SDW analysis of middle and late reproductive stages. SDW data of early reproductive stage were used as the covariate for marketable yield of middle reproductive stage and marketable yield of late reproductive stage was analyzed using covariate as the yield data of middle reproductive stage. The mean separation was done using Duncan's new Multiple Range Test (DnMRT) procedure using statistical software, SAS (ver. 9, SAS Institute, Cary, NC). Significances of treatment means were determined at $\mathrm{P}<0.05$.

\section{RESULTS AND DISCUSSION}

\section{Vegetative growth stage of tomato (1-3 WAT)}

During the vegetative growth stage [3 WAT (weeks after transplanting)], growth parameters were not affected by $\mathrm{K}$ treatments. The mean plant height, number of leaves, leaf area, length of the 3rd leaf and stem diameter were $60 \pm 0.8 \mathrm{~cm}, 11.65 \pm 0.28$, $0.16 \pm 0.02 \mathrm{~m}^{2} /$ plant, $21.6 \pm 0.26 \mathrm{~cm}$ and $1.7 \pm 0.04 \mathrm{~cm}$ respectively. The shoot dry weight was also not significantly different among the treatments and mean shoot dry weight was $14 \pm 01 \mathrm{~g} / \mathrm{plant}$. According to the Growing greenhouse vegetables (2010), properly nourished tomato plants may have a $10 \mathrm{~mm}$ stem diameter at $15 \mathrm{~cm}$ below the growing tip, during the vegetative growth, and all $\mathrm{K}$ treatments at this stage were found to be within this standard. Mean leaf area, plant height and leaf number at this growth stage were almost similar to earlier reports for greenhouse tomato (Herath et al., 2008; Weerakkody et al., 2007). This confirmed the adequacy of the least amount of $\mathrm{K}$ rate for maintaining the plant growth during the vegetative stage of tomato and this was well below the mean $\mathrm{K}$ rates applied at the vegetative stage by commercial farmers in Sri Lanka 0.25 $\mathrm{g} /$ plant/day) as reported by Erabadupitiya et al., (2019).

The lowest (1.8\%) and highest (3.3\%) plant tissue $\mathrm{K}$ concentration $[\mathrm{K}]$ were found at the lowest $(0.05$ $\mathrm{g} /$ plant/day) and highest $(0.4 \mathrm{~g} / \mathrm{plant} /$ day $) \mathrm{K}$ application rate treatments respectively. Tissue $[\mathrm{K}]$ of treatment 2 to 5 were not significantly different (Figure 1), which were within the adequate range, reported earlier (Hochmuth et al., 2012). Therefore, the treatment $2(0.1 \mathrm{~g} / \mathrm{plant} /$ day $)$ can be selected as the minimum $\mathrm{K}$ rate required in this vegetative stage of tomato. Plant tissue concentration of nitrogen $[\mathrm{N}]$, phosphorus $[\mathrm{P}]$, calcium [Ca] and magnesium $[\mathrm{Mg}]$ were not affected by the $\mathrm{K}$ treatments and mean values were $4.1 \pm 0.1, \quad 0.6 \pm 0.06, \quad 1.4 \pm 0.12$ and $0.4 \pm 0.01$ respectively in vegetative stage of tomato.

\section{Early reproductive stage of tomato (4-7 WAT)}

The results showed that, there was no significant effect of covariates (LA and SDW of vegetative stage) on leaf area ( $\mathrm{p}=0.1543)$, shoot dry weight $(p=0.5570)$ and number of flower clusters $(p=0.7288)$ in early reproductive stage. However, the treatment effects were significant.

At the end of early reproductive/flowering stage, number of flower clusters, leaf area and shoot dry weight were significantly higher at $\mathrm{K}$ application rates above T2 (0.2 g/plant/day) (Table 2). When increasing the $\mathrm{K}$ rate from 0.2 to $0.55 \mathrm{~g} / \mathrm{plant} / \mathrm{day}$, number of flower clusters did not show a significant further increase. As reported by Fontes et al., (2000) higher number of flower clusters could contribute to a higher yield and thus the $\mathrm{K}$ application rate corresponding to the significantly 
higher number of flower clusters can be considered to be the optimum at this stage of tomato. Meanwhile, there was no significant change in plant diameter $(3.53 \pm 0.02 \mathrm{~cm})$ in response to $\mathrm{K}$ application rates. Therefore, the $\mathrm{K}$ application rate of $0.2 \mathrm{~g} / \mathrm{plant} /$ day (T2) could be identified as the optimum dosage at the early reproductive stage of tomato.

Tissue $[\mathrm{K}]$ at this stage was significantly higher in T7 $(0.55 \mathrm{~g} /$ plant/day), the highest $\mathrm{K}$ application rate compared to other treatments. The corresponding tissue $[\mathrm{K}]$ of T2 $(0.2 \mathrm{~g} /$ plant/day $)$, the selected $\mathrm{K}$ application rate was $2.1 \%$ (Figure 1 ). Although this level was lower than the earlier reported adequate range (Hochmuth et al., 2012), contribute to have higher number of flower clusters and crop growth in this stage. Leaf tissue [K] was low at this stage may be due to the $\mathrm{K}$ partitioning for flower cluster formation, without showing deficiency symptoms. Plant tissue N, P, Ca and $\mathrm{Mg}$ concentrations $(4.2 \pm 0.6,0.5 \pm 0.06,1.7 \pm 0.4$, and $0.25 \pm 0.06 \%$, respectively) did not show significant treatment effect. Similar to the vegetative growth stage they were within the adequate ranges, reported earlier.

\section{Middle reproductive stage of tomato (8-11 WAT)}

The selected covariates (LA and SDW of early reproductive stage) effect was insignificant on LA $(\mathrm{p}=0.4529$.$) , shoot dry weight (\mathrm{p}=0.9441)$ and Marketable yield $(p=0.5743)$ in middle reproductive stage of tomato.

At this stage, the early harvest of tomato was assessed with respect to $\mathrm{K}$ treatments. Compared to other $\mathrm{K}$ application rates, shoot dry weight and marketable yield were higher at the $\mathrm{K}$ application range of $0.3-0.5 \mathrm{~g} / \mathrm{plant} /$ day while the leaf area was not affected by the treatments (Table 3 ). At the fruit harvesting stage, comparatively higher plant nutrient supply is required for plant growth and fruit development (Liu, 2019). The $\mathrm{K}$ rate of 0.3 g/plant/day (T2) could be identified as the optimum $\mathrm{K}$ dosage for the middle reproductive stage of tomato.

Table 2. Effect of $\mathrm{K}$ application rates on growth parameters at the early reproductive stage of tomato.

\begin{tabular}{ccccc}
\hline $\begin{array}{c}\text { K-rate } \\
\text { (g/plant/day) }\end{array}$ & $\begin{array}{c}\text { Stem diameter } \\
\text { (cm) }\end{array}$ & $\begin{array}{c}\text { No. of flower } \\
\text { clusters/plant }\end{array}$ & $\begin{array}{c}\text { Shoot dry weight } \\
\text { (kg/plant) }\end{array}$ & $\begin{array}{c}\text { Leaf area } \\
\left.\mathbf{( m}^{\mathbf{2}} / \mathbf{p l a n t}\right)\end{array}$ \\
\hline 0.10 & $3.52^{\mathrm{a}}$ & $4.8^{\mathrm{b}}$ & $0.09^{\mathrm{b}}$ & $0.66^{\mathrm{b}}$ \\
0.20 & $3.55^{\mathrm{a}}$ & $5.8^{\mathrm{a}}$ & $0.12^{\mathrm{a}}$ & $0.86^{\mathrm{a}}$ \\
0.30 & $3.55^{\mathrm{a}}$ & $6.0^{\mathrm{a}}$ & $0.13^{\mathrm{a}}$ & $0.92^{\mathrm{a}}$ \\
0.35 & $3.53^{\mathrm{a}}$ & $5.8^{\mathrm{a}}$ & $0.13^{\mathrm{a}}$ & $0.90^{\mathrm{a}}$ \\
0.40 & $3.51^{\mathrm{a}}$ & $5.8^{\mathrm{a}}$ & $0.13^{\mathrm{a}}$ & $0.97^{\mathrm{a}}$ \\
0.50 & $3.54^{\mathrm{a}}$ & $5.9^{\mathrm{a}}$ & $0.12^{\mathrm{a}}$ & $0.93^{\mathrm{a}}$ \\
0.55 & $3.53^{\mathrm{a}}$ & $5.9^{\mathrm{a}}$ & $0.12^{\mathrm{a}}$ & $0.88^{\mathrm{a}}$ \\
\hline
\end{tabular}

Values in columns followed by the same letter are not significantly different (DMRT $/ p<0.05$ ).

Table 3: Effect of $\mathrm{K}$ application rates on growth parameters and yield at middle reproductive stage of tomato.

\begin{tabular}{cccc}
\hline $\begin{array}{c}\text { K-rate } \\
\text { (g/plant/day) }\end{array}$ & $\begin{array}{c}\text { Leaf area } \\
\left(\mathbf{m}^{2} / \text { plant) }\right.\end{array}$ & $\begin{array}{c}\text { Shoot dry weight } \\
\text { (kg/plant) }\end{array}$ & $\begin{array}{c}\text { Marketable yield } \\
\text { (kg/plant) }\end{array}$ \\
\hline 0.20 & $1.29^{\mathrm{a}}$ & $0.13^{\mathrm{ab}}$ & $1.42^{\mathrm{b}}$ \\
0.30 & $1.31^{\mathrm{a}}$ & $0.16^{\mathrm{a}}$ & $2.02^{\mathrm{a}}$ \\
0.40 & $1.34^{\mathrm{a}}$ & $0.16^{\mathrm{a}}$ & $1.91^{\mathrm{a}}$ \\
0.45 & $1.33^{\mathrm{a}}$ & $0.16^{\mathrm{a}}$ & $1.89^{\mathrm{a}}$ \\
0.50 & $1.32^{\mathrm{a}}$ & $0.16^{\mathrm{a}}$ & $1.90^{\mathrm{a}}$ \\
0.55 & $1.31^{\mathrm{a}}$ & $0.14^{\mathrm{ab}}$ & $1.56^{\mathrm{b}}$ \\
0.60 & $1.29^{\mathrm{a}}$ & $0.13^{\mathrm{ab}}$ & $1.48^{\mathrm{b}}$ \\
\hline
\end{tabular}

Values in columns followed by the same letter are not significantly different (DMRT $/ p<0.05$ ). 


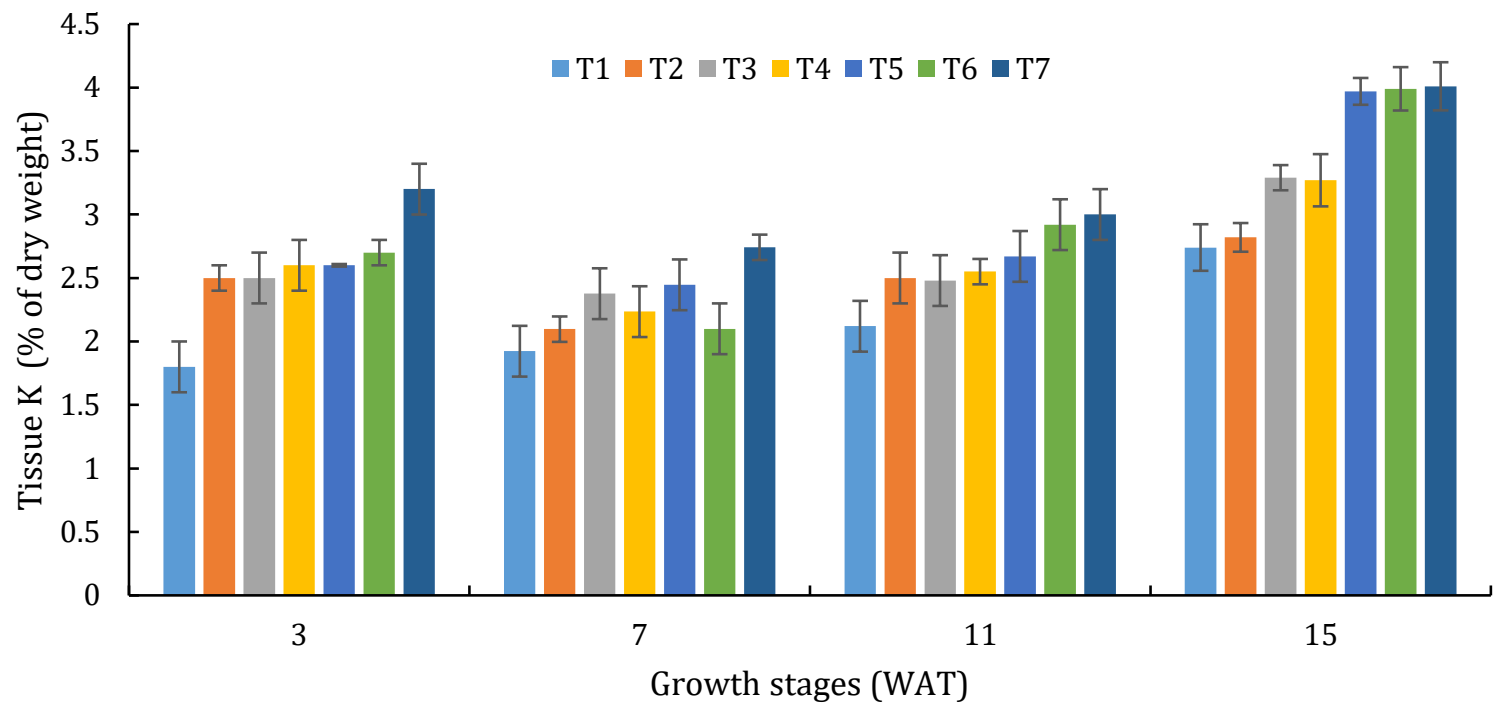

Figure 1. Interaction of $\mathrm{K}$ treatments and tissue $[\mathrm{K}]$ of tomato at different growth stages.

Plant tissue $[\mathrm{K}]$ was in an increasing trend with the increase in $\mathrm{K}$ application rates and Locascio et al., (1997), reported a same scenario. The [K] 01) which was within the adequate tissue $[\mathrm{K}]$ at fruiting stage of tomato (Hochmuth et al., 2012). Similar to early growth stage, the mean $\mathrm{N}$ $(4.5 \pm 0.2 \%), \mathrm{P}(0.4 \pm 0.05 \%)$ and $\mathrm{Ca}(1.5 \pm 0.2 \%)$ contents were also within the adequate range. (Hochmuth et al., 2012). In contrast, The tissue Mg content showed a decreasing trend along with the increasing $\mathrm{K}$ application rate (Figure 02), but the [Mg] corresponding to the $\mathrm{K}$ rate of $0.3 \mathrm{~g} / \mathrm{plant} /$ day was $0.28 \%$ which was within the adequate range.

\section{Late Reproductive Stage of tomato (12-15 WAT)}

Similar to the middle reproductive stage, covariates effect could be excluded, since the results were not significantly affected on LA $(\mathrm{p}=0.6831)$, SDW $(\mathrm{p}=0.1750)$ and marketable yield $(p=0.5412)$ in this stage.

The significantly higher leaf area, and marketable yield could be found at the $\mathrm{K}$ rate of $0.35-0.55$ g/plant/day (T2-T5), compared to lower and higher extremes in K supply. The shoot dry weight, fruit diameter and fruit weight were also significantly higher in these treatments (Table 4). Therefore, the lowest $\mathrm{K}$ rate corresponding to maximum yield and overall crop growth at this stage, $0.35 \mathrm{~g} / \mathrm{plant} /$ day could be selected as the optimum $\mathrm{K}$ dosage for late reproductive stage of tomato. Usually the peak fruiting stage requires great amount of nutrients as reported by Hochmuth et al., (2001).

Table 4: Effect of $K$ application rates on growth parameters and yield at late reproductive stage of tomato.

\begin{tabular}{cccccc}
\hline $\begin{array}{c}\text { K-rate } \\
\text { (g/plant/day) }\end{array}$ & $\begin{array}{c}\text { Leaf area } \\
\left(\mathbf{m}^{2} / \text { plant) }\right.\end{array}$ & $\begin{array}{c}\text { Shoot dry } \\
\text { weight } \\
\text { (kg/plant) }\end{array}$ & $\begin{array}{c}\text { Marketable } \\
\text { yield } \\
\text { (kg/plant) }\end{array}$ & $\begin{array}{c}\text { Fruit } \\
\text { diameter } \\
(\mathbf{c m})\end{array}$ & $\begin{array}{c}\text { Fruit } \\
\text { weight } \\
\text { (g/fruit) }\end{array}$ \\
\hline 0.25 & $1.55^{\mathrm{ab}}$ & $0.155^{\mathrm{b}}$ & $2.01^{\mathrm{b}}$ & $16.5^{\mathrm{b}}$ & $112.6^{\mathrm{b}}$ \\
0.35 & $1.65^{\mathrm{a}}$ & $0.175^{\mathrm{a}}$ & $2.44^{\mathrm{a}}$ & $19.6^{\mathrm{a}}$ & $129.9^{\mathrm{a}}$ \\
0.45 & $1.64^{\mathrm{a}}$ & $0.177^{\mathrm{a}}$ & $2.53^{\mathrm{a}}$ & $20.1^{\mathrm{a}}$ & $137.2^{\mathrm{a}}$ \\
0.50 & $1.65^{\mathrm{a}}$ & $0.176^{\mathrm{a}}$ & $2.51^{\mathrm{a}}$ & $21.2^{\mathrm{a}}$ & $137.7^{\mathrm{a}}$ \\
0.55 & $1.64^{\mathrm{a}}$ & $0.178^{\mathrm{a}}$ & $2.48^{\mathrm{a}}$ & $20.8^{\mathrm{a}}$ & $146.3^{\mathrm{a}}$ \\
0.60 & $1.57^{\mathrm{ab}}$ & $0.175^{\mathrm{a}}$ & $1.96^{\mathrm{b}}$ & $19.8^{\mathrm{a}}$ & $131.2^{\mathrm{a}}$ \\
0.65 & $1.43^{\mathrm{b}}$ & $0.156^{\mathrm{b}}$ & $1.87^{\mathrm{b}}$ & $17.4^{\mathrm{b}}$ & $115.3^{\mathrm{b}}$ \\
\hline
\end{tabular}

Values in columns followed by the same letter are not significantly different (DMRT $/ \mathrm{P}<0.05$ ). 


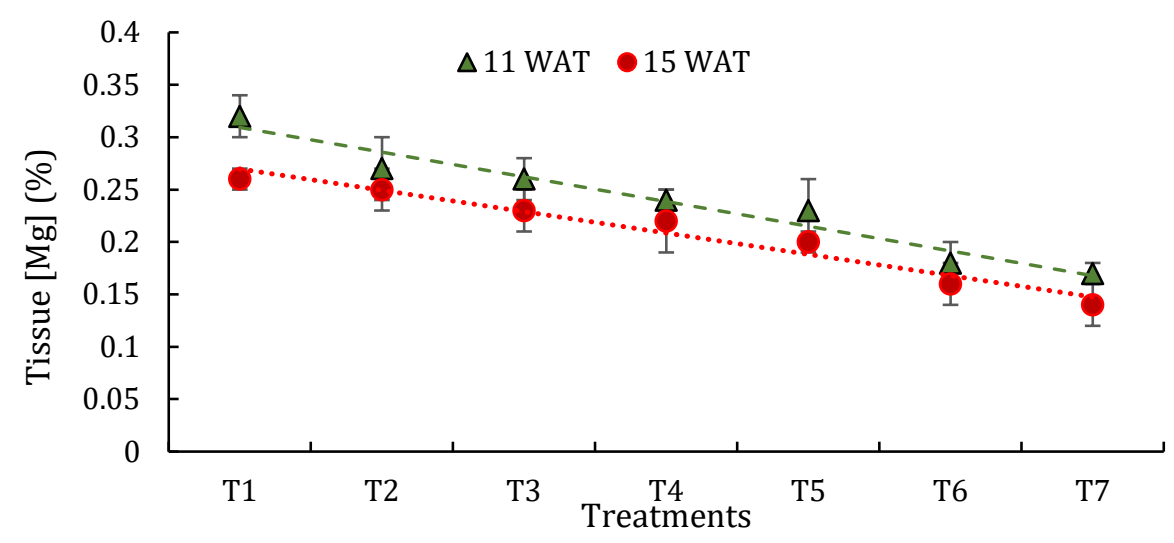

Figure 2. Relationship between tissue [Mg] and $\mathrm{K}$ treatments in middle (11 WAT) and late (15 WAT) reproductive stages of tomato

Similar to middle reproductive stage, plant tissue $[\mathrm{K}]$ of tomato increased with increasing $\mathrm{K}$ rates at the late reproductive stage (Figure 1). This trend is agreed with the previously published data for tomato (Locascio et al., 1997). The tissue [K] corresponding to the selected optimum $\mathrm{K}$ application rate $(0.35 \mathrm{~g} /$ plant/day $)$ was $2.8 \%$ (Figure 1), just above the upper limit reported by Hochmuth et al. (2012). Leaf tissue concentrations of $N(4.5 \pm 0.3 \%), P(0.35 \pm 0.06 \%)$, Ca $(1.6 \pm 0.1 \%)$ and $\mathrm{Mg}$ at the optimum $\mathrm{K}$ application rate 0.35 $\mathrm{g} /$ plant/day) were also remained within adequate range (Hochmuth et al., 2012). Negative response for some growth parameters, fruit diameter and weight, finally the yield, to further increase of $\mathrm{K}$ rates may be due to Mg deficiency (Figure 2). Decreasing tissue $[\mathrm{Mg}]$ with increasing tissue $[\mathrm{K}]$ of tomato could be described as a physical barrier of entering through the cellular membrane of the roots, may be due to the competition of nutrient (Ortas, 2013; Jones, 2005).

Measuring leaf nutrient contents indicate tomato plants absorb major plant nutrients at different rates during different growth stages, because of the variability of their demands (Terabayashi et al., 1991). Considering overall crop growth and yield due to the cumulative effect of $\mathrm{K}$ treatment 2 of each growth stage $(0.1,0.2,0.3$ and 0.35 $\mathrm{g} /$ plant/day for vegetative, early reproductive, middle and late reproductive stages, respectively) can be selected as optimum $\mathrm{K}$ application rates required for soilless culture tomato grown in coco peat medium. Further increase of $\mathrm{K}$ application rate did not significantly increase the plant growth or yield of tomato. It supports the inference made by earlier researchers on lack of further yield improvements in response to increasing $\mathrm{K}$ application rates, as excess $\mathrm{K}$ supply can reduce the absorption of some other plant nutrients (Jones, 2005; Liu, 2019).

\section{CONCLUSIONS}

Considering the growth parameters and marketable yield in the main growth stages of tomato, the optimum $\mathrm{K}$ fertilizer application rates could be identified as $0.1,0.2,0.3$ and 0.35 $\mathrm{g} /$ plant/day for vegetative, early reproductive, middle reproductive and late reproductive stages, respectively. The corresponding tissue $[\mathrm{K}]$ of these $\mathrm{K}$ application rates were 2.5, 2.1, 2.5 and $2.8 \%$ at the same growth stages, respectively. These growth stage specific optimum $\mathrm{K}$ application rates were able to maintain the plant growth and flowering at their optimum and formation of the highest marketable yield of relatively large fruits (higher fruit weight and fruit diameter) in cocopeat based soilless culture of tomato under hot and humid greenhouse environmental conditions in Sri Lanka. These established optimum $\mathrm{K}$ application rates and critical tissue $\mathrm{K}$ concentrations would be used as standards for determining $\mathrm{K}$ fertilizer dosages of soilless culture tomato under a range of greenhouse environmental conditions, especially in the tropical region. Relatively low optimum $\mathrm{K}$ application rates identified in this research is meritorious for managing the economic and environmental sustainability of greenhouse agriculture in the tropics.

\section{ACKNOWLEDGMENT}

The research supported by the Research Facilitating Fund (RFF) grant from the Post Graduate Institute of the Agriculture, University of Peradeniya, Peradeniya, Sri Lanka. 


\section{REFERENCES}

Almeselmani, M., Pant, R.C. and Singh, B. (2010). Potassium level and physiological response and fruit quality in hydroponically grown tomato, Inter. Journal of Vegetable Science. 16(1), 8599.

Bryson, G.M. and Barker, A.V. (2002). Determination of optimal fertilizer concentration range for tomatoes grown in peat-based medium, Communications in Soil Science and Plant Analysis, 33, 759-777

Bar-Yosef, B. 1992. Fertilization under drip irrigation, Haifa greenhouse crop guide. Haifa Group, Haifa, Israel. [on line]. [Accessed on 25.07.2020]. https://www.haifa-group.com/ articles/crop-guide-growing-tomato

Campbell, C.R. (2000). Reference sufficiency ranges for plant analysis in the southern region of the United States Southern Coop. Ser. Bull. 394, North Carolina Department of Agriculture and Consumer Services, Agronomic Division, Raleigh, NC.

Cresswell, C.G. (1992). Coir dust- a proven alternative to peat [on line]. [Accessed on 29.09.2019]. Available at http://www. cocopeat.com.au/technical/productAnalysis/p df/Cresswelldoc.pdf

Erabadupitiya, H.R.U.T., Weerakkody, W.A.P. and Nandasena, K.A. (2020). Critical nitrogen ranges for growth stages of tomato in soilless culture under greenhouse conditions in the tropics, International Journal of Vegetable Science. [on line]. [Accessed on 09.10.2020]. Available at https://www.tandfonline.com/ doi/full/10.1080/19315260.2020.1821144

Erabadupitiya, H.R.U.T., Galaboda, J.K. and Weerakkody, W.A.P. (2019). Assessment of existing fertigation protocols in protected culture with respect of marketable yield. Trop. Agriculturist, 167(1), 68-80

Fontes, P. C. R., Sampaio, R. A. and Mantovani, E. C. (2000). Tomato yield and potassium concentrations in soil and in plant petioles as affected by potassium fertirrigation. Pesquisa Agropecuaria Brasileira, 35, 575-580.

Growing Greenhouse Vegetables in Ontario. (2010). Tomato, Ministry of Agriculture, Food and Rural affairs. Queen's printer, Ontario, Canada. pp. 35-51.
Herath, H.M.N.K., Sooriyagoda, L.D.B., Amarasiri, K.E.S.N., Premaratne, K.P. and Weerakkody, W.A.P. (2008). Applicability of straight fertilizers and compost in greenhouse tomato cultivation. Sri Lankan Journal of Agricultural Science, 45, 33-46.

Hochmuth, G.J., Maynard, D., Vavrina, C., Hanlon, E. and Simonne, E. (2012). Plant tissue analysis and interpretation for vegetable crops in Florida. Handbook on nutrient management of vegetable and row crops, University of Florida. Univ. Press, FL.

Hochmuth, G.J. (2001). Fertilizer management for greenhouse vegetables. Florida greenhouse vegetable production handbook, University of Florida. [on line]. [Accessed on 10.02.2018]. Available at https://edis.ifas.ufl.edu/pdffiles/ CV/CV26500.pdf

Jones, J.B. (2005). Hydroponics: A practical guide for the soilless grower. Boca Raton, Florida: CRC Press.

Liu, J., Hu, T., Feng, P., Wang, L., and Yang, S. (2019). Tomato yield and water use efficiency change with various soil moisture and potassium levels during different growth stages. [on line]. [Accessed on 15.07.2019]. Available at https://journals.plos.org/plosone/article?id=1 0.1371/journal.pone.0213643

Liu, K., Zhang, T. Q., Tan, C. S., and Astatkie, T. (2011). Responses of fruit yield and quality of processing tomato to drip-irrigation and fertilizers phosphorus and potassium. Agronomy Journal, 103(5), 1339-1345.

Locascio, S.J., Hochmuth, G.J., Rhoads, F.M., Olson, S., Smajstrla, A.G. and Hanlon, E.A. (1997). Nitrogen and potassium application scheduling effects on drip-irrigated tomato yield and leaf tissue analysis. Horticultural Science, 32, 230235.

Mawalagedera, S., Weerakkody, W.A.P. and Premaratne, K. (2012). Circulation culture of tomato for efficient nutrient uptake and high yield in tropical greenhouses. Tropical Agriculture Research, 23(3), 204-207.

Ortas, I. (2013). Influences of nitrogen and potassium fertilizer rates on pepper and tomato yield and nutrient uptake under field conditions. Scientific Research and Essays Academic Journals, 8(23), 1048-1055 
Passam, H., karapanos, I., Bebeli, P., \& Savvas, D. (2007). A review of recent research on tomato nutrition, breeding and post-harvest technology with reference to fruit quality. The European Journal of Plant Science and Biotechnology, 1(1), 1-21.

Putra, P.A. and Yuliando, H. (2015). Soilless culture system to support water use efficiency and product quality: a review. Agriculture and Agricultural Science Procedia, 3, 283-288.

Sainju, U.M., Dris, R. and Singh, B. (2003). Mineral nutrition of tomato. Journal of Food, Agriculture and Environment, 1(2), 176-184.

Saparamadu, M.D.J.S., Weerakkody, W.A.P., Wijesekara, R.D. and Gunawardhna, H.D. (2011). Development of a low cost hydroponic system and a formulation for the tropics. Journal of Applied Horticulture, 13, 68-70.

Terabayashi, S., Takii, K. and Namiki, T. (1991). Variation in diurnal uptake of water and nutrients by tomato plants of different growth stages grown in water culture, Journal of the Japanese Society for Horticultural Science. 59(4), 751-755.

Truffault, V., Marlrnr, R., Brajeul, E., Vercambre, G. and Gautier, H. (2019). To stop nitrogen overdose in soilless tomato crop: A way to promote fruit quality without affecting fruit yield. Agronomy Journal, 9(2), 80-88

Uchida, R.S. (2000). Recommended plant tissue nutrient levels for some vegetable, fruit, and ornamental foliage and flowering plants in Hawaii, pp. 57-67. In: Silva, J.A. and R.S. Uchida (Ed.). Plant nutrient management in Hawaii's soils: Approaches for tropical and subtropical agriculture. University Press, Honolulu, HI.

Voogt, W. (2002). "Potassium management of vegetables under intensive growth conditions. pp.126-130. In: Pasricha, N.S. and Bansal SK (Ed.), international potash institute, Bern, Switzerland.

Voogt W. and Korsten P. (1996). Mineral balances for radish crops grown under glass. Acta Horticulture, 428, 53-64.

Weerakkody, W.A. P., Wahundeniya, K.B. and Yasakethu. K. (2008). Arakshitha Gruhathula Bhoga wagawa (Greenhouse Crop cultivation), Interactive CD ROM, Department of Agriculture, Peradeniya, Sri Lanka.

Weerakkody, W.A.P., Mayakaduwa, M.A.P. and Weerapperuma, K.N. (2007). Effect of supply volume and weather based EC adjustments on the growth and yield of greenhouse tomato and bell pepper. Acta Horticulture, 742, 105-111. 